\title{
5 Changing expertise and the state
}

\author{
Risto Rinne, Xingguo Zhou, Jaakko Kauko, \\ Romuald Normand, Anna Medvedeva, \\ and Íris Santos
}

\section{Introduction}

Although the state is still a relevant and powerful concept in legitimising actors and directing policy, legitimation through data ownership and experts' instrumental knowledge has become a means of finding more room for action. Several studies have affirmed the role of knowledge in the shaping of education policy and implementation of education reforms on both national and global levels (Normand 2017; Lawn \& Normand 2014). Expertise plays a crucial role in the production and interpreting of knowledge. It is "a specific activity of knowledge production participating in the process of negotiation and orientation of public policy" (Normand 2017: p. 74; see also Ozga 2011). This knowledge is mainly technical and prescriptive/normative and derives from the "professionals working in administrations of the states, international organisations, universities and the HE institutions, agencies, think tanks or interest groups" (Normand 2017: p. 74; see also Weible 2008). Policy arenas like consensus conferences are also central to the academic production of knowledge with various structures and conditions of reception (see Weiss 1979).

In some epistemic communities, experts are mandated and certified to participate in the entire collective learning process. Policymakers thus call on expertise in seeking to reduce uncertainty about information and knowledge in decision-making processes. As Normand (2017: p. 75) writes: "Experts are controlled because it is policy-makers who make the decisions regarding the modalities of dissemination and the use of knowledge. Experts have to respect precise specifications defining the modalities of reciprocal learning and knowledge production." Such policy-expert acquaintances are a means of producing knowledge based on personal relationships between experts and policymakers which differs from the division of labour orchestrated by knowledge centres for the production of evidence-based resources. Types and organisations of expertise differ significantly in serving policymaking.

In some cases, experts have considerable capacity to anticipate emerging political issues because of their previous political and administrative experience and capacity to represent and lead important expert networks. The capacity of anticipation has also shifted from states' and international organisations' 
expertise in traditional planning and prospecting to international consultancy groups like McKinsey or Pearson, with the capacity to elaborate short-term scenarios and knowledge-based technologies and resources. Depending on their influence on and closeness to the media, experts affect the communication and interpretation of selected research findings and studies differently from various groups and audiences. They usually strive to directly influence the media and specific target groups "by adopting a clear, concise and understandable language while using media devices at their disposal (blogs, Facebook, Twitter, etc.)" (Normand 2017: p. 76).

This chapter analyses and contextualises the changing role and relationship of the state and expertise in Brazil, China, and Russia, when large-scale policies of quality assurance and evaluation in school education have been undertaken. Our main question concerns the nature of expertise in reshaping the state's context, status, possibilities, and limits in governing education reforms through quality assurance and evaluation (QAE). In contrast with Chapter 4, this chapter focuses more on the national level than international organisations. Chapter 6 returns to a closer examination of the processes experts conduct.

Usually, the state's interest and approval seek to determine the development and application of QAE, and this is also empowered and supported by QAE data. However, the data generated by various instruments and databases greatly depend on experts, who in many cases generate the lexicon and concepts of data use. Independent experts devise their own instruments and data analysis, but state authorities and structures create a wider, but also restrictive, demand for data collection and use. Concurring data collections exist, which seek to adjust the information collected but which may overload the system. Experts may therefore find their room for action diminished. There is a general mismatch between the demands of experts and state officials. Independent experts' access to state-owned data is also often limited. The roles of and relationship between the state and expertise seem to vary greatly in Brazil, China, and Russia. To tackle these differences, we ask the following sub-questions:

- Who are the main experts in Brazil, China, and Russia recognised as responsible and legitimate actors to collect and interpret data in the QAE of school education policies?

- What kind of relationship and division of labour is there in Brazil, China, and Russia between the state and experts, and is there evidence that this relationship is changing?

- Are the experts and/or state authorities and policymakers willing to limit and restrict or widen and open data use in their practice of the education policies grounded in QAE?

In the next section, we analyse the state's changing role in the historical and social situation of the twenty-first century, which has seen growing global, international, and transnational influences and impacts on nation-states. The third section discusses and analyses experts' growing and changing roles. Our main 
theoretical and empirical points of departure here derive from the wide and deep research tradition of sociology, the political sciences, and comparative educational science in the fields of the state and the changing role of expertise. Most of the research we use here has been undertaken by Western researchers within the frame of the Western research tradition, and it is also interwoven with the views of international organisations such as the Organisation for Economic Cooperation and Development (OECD) and the European Union and the Western worldview. In this respect, they are manifested in many ways in the relatively rich welfare states and may contain angles and perspectives which inadequately fit the circumstances, economies, and social, cultural, and educational heritages of the "emerging countries", to which Brazil, China, and Russia are often said to belong. We are deeply aware of this potential bias and seek to address it seriously in our framework's critical challenge, theory formation, discussion, and analysis. After the theoretical sections on state and expertise, the following three sections analyse and seek to answer our research questions empirically, drawing largely on interview data from each of our case countries. The final section summarises our comparison of Brazil, China, and Russia and takes issue with the more theoretical discussion about the changing relationship between expertise and the state, using the idea of CADEP to understand actors' roles and dynamics.

We conclude by reflecting on the dynamics of attempts to govern the education policies of nation-states with evidence-based technologies through data, numbers, and indicators. The state's role is also shaken by the many profound changes within the countries, including the partial loosening of its strict monopoly of collective decision-making and the new pressures to decentralise and deregulate it, which creates more room for different actors and actor groups, as well as the growing number of experts.

\section{The changing role of the state}

Bauman (1987, 1992, 1998, 2004) has replaced his older concept of "postmodernity" with the concept of "liquid modernity". He emphasises that there are no stable institutions or conditions in the global age and that there are no frames because everything everywhere is constantly in process. "While trust and confidence were constitutive of early modernity, risk and uncertainty are now the hallmarks of liquid modernity" (cited in Kwiek 2006: p. 306). In liquid modernity, the traditional post-war Keynesian welfare state, with its powerful state institutions, is questioned. Current transformations are giving birth to profitability and to "a new kind of capitalism, a new kind of economy, a new kind of global order, a new kind of society and a new kind of personal life" (Beck 1999: p. 2, cited in Kwiek 2006: p. 27; Rinne \& Ozga 2011). Where our chapter's focus is concerned, this should also affect the relationship between the state and experts.

These changing questions of power boil down to the term "governance", which is used in many social science disciplines as an interdisciplinary bridging concept (see Schuppert 2006: p. 373). There is no agreed-upon definition 
of the term: governance is used to describe new forms of steering/regulation (Benz 2004). From the outset, it is important to note that governance is not a narrow theory but rather an analytical approach which draws attention to important changes in political perspective. These shifts in perspective concern the use of governance to conceptualise regulatory and governance activities which concepts such as "steering", "governing", "control", and "interdependence" have conventionally favoured. Governance addresses "government", "management", "coordination", "regulation", and so on among the different actors within the state, market, economy, and civil society non-hierarchical and network structures (Benz et al. 2007; Ball \& Junemann 2012; Loncle, Parreira do Amaral, \& Dale 2015).

Governance emerged as a political concept at a time of criticism and scepticism concerning the possibilities for a linear and hierarchical regulation of complex social systems. This points as much to a change of perspective concerning forms of regulation and coordination in modern societies as it does to any profound transformation (Mayntz 2006; Dale et al. 2016).

Patrick Le Galès defines the substance of governance as

[A] coordination process of actors, social groups and institutions that aims at reaching collectively defined and discussed objectives. Governance then concerns the whole range of institutions, networks, directives, regulations, norms, political and social uses as well as public and private actors which contribute to the stability of a society and a political regime, to its orientation, to its capacity to lead, to deliver services and to assume its legitimacy. (Le Galès 2004: p. 243; cited in Dale et al. 2016)

Changes in governance resulting from the new steering tools the expert community usually uses have been widely noted. In Chapter 6, we present a critique of Rose's and Miller's idea of "steering at a distance", which follows from the analysis of our case countries. However, it is helpful to understand that the principles of calculability and measurability originating from economics used by the private sector have increasingly been transferred to fields previously regulated by old bureaucratic statutes and professional norms, usually located in the public sector. Rose (1999: p. 152) refers to the new governance technology based on accountability and assessment to which the public sector is subjected as "governance at a distance" (Rinne \& Ozga 2011: p. 67). This steering has consequences, as Rose puts it, for the shift to an "audit society", where every new space subjected to comparability, measurability, and transparency summons its population to evaluate and measure itself and translates its activities into measurable and economic language to maximise efficiency and income, while arbitrary rules are "tamed, liberalized and acknowledged as neutral and objective calculation and evaluation" (Rose 1999: pp. 152-154; Rose \& Miller 1992, cited in Rinne 2001: p. 107).

Similarly, Michael Power has developed the concept of the "global inspectorate or audit society" (1999, 2003), and he observes that evaluation entails 
a "control of controls" and "rituals of verification" (cited in Rinne \& Ozga 2011). In political science, the focus on understanding governance structures and processes as opposed to governments' structures and processes occurred more than a decade ago. Briefly, this focuses on the shift from centralised and vertical hierarchical forms of regulation to decentralised, horizontal, networked forms (e.g., Rosenau 1999). Although it is widely acknowledged that governance is a phenomenon which produces broad patterns reflecting dominant political forces, it is also important to note that it is understood as a continuum which "stretches between the transnational and the subnational, the macro and the micro, the informal and the institutionalized, the state-centric and the multicentric, the cooperative and the conflictual" (Rosenau 1999 cited in Ozga et al. 2011: pp. 89-90).

Where steering tools are concerned, the OECD's knowledge-based regulatory tools vigorously attempt to promote orthodox professional practice and the increased standardisation of professional formation and development. The strength and power of these tools lie in their apparently objective nature, in the attractiveness of the space for negotiation and debate they create in which experts, policymakers, and other knowledge-brokers meet and position themselves, and in their capacity to define the terms of that engagement (Rinne \& Ozga 2013: p. 97). Pons and Van Zanten (2007) suggest these tools have three main elements: (i) they reflect particular "world visions" which represent the agenda-setting capacities of particular interests; (ii) they represent a particular and politically oriented set of beliefs concerning legitimate policy in a given domain; and (iii) they represent a wide and growing network of actors who are constantly drawn into the process of intelligencegathering, auditing, and reflective policymaking (cited in Rinne \& Ozga 2013: p. 97).

To grasp the implications of the increasing complexity of the emerging multi-scalar/multi-level governance arrangements in each country, we need to devise a new lens through which to examine the issues. Dale sees this as a major shift:

With new forms of complex governance, the state form ... loses its monopoly position in the production of collective solutions to the collective problems. Collectively binding decisions are no longer taken by the state alone, or among sovereign states, but rather with the involvement of various types of societal actors, sometimes even without governments.

(Dale 2009: p. 30)

Dale and Robertson (2012: p. 23) make a similar argument and emphasise a change in the

national education system to a more fragmented, multi-scalar and multisectoral distribution of activity that now involves new players, new ways of thinking about knowledge production and distribution, and new challenges 
in terms of ensuring the distribution of opportunities for access and social mobility.

(see also Dale 2003)

Verger, Lubienski, and Steiner-Khamsi (2016: p. 4) also analyse the growth of the "global education industry" and observe that its emergence has entailed the development of new market niches "that are often outside of traditional state control, such as preparation, edu-marketing, the provision of curriculum packages or school improvement services".

However, it is important not to exaggerate the state's defeat here and succumb to what Weiss (1997) calls "the myth of the powerless state" (cited in Ball 2007: p. 36). Indeed, despite an increasing international interdependence which seems to generate pressure to converge, advanced industrial societies continue to exhibit differences in their institutional practice. As Andy Green (1999: p. 56) observes,

As regards education, there is very little evidence across the globe that nation states are losing control over their education systems or ceasing to press them into service for national economic and social ends, whatever the recent accretions of internationalism. In fact the opposite may be true. As governments lose control over various levers on their national economies and cede absolute sovereignty in foreign affairs and defence, they frequently turn to education and training as two areas where they do still maintain control.

The orthodox conception of national education systems effectively draws together distinct functions and sets of rules and beliefs. Those which have been

historically rooted in an assumption of the centrality of national economies for instance, that the function of education systems was to provide educated labour for the national economy and that education systems would shift and separate the potential workforce, according to ability and potential contribution to the economy. Another assumption was that education systems are crucial to the construction of national culture, integration and sense of national belonging.

(Parreira do Amaral \& Rinne 2015: pp. 80-81)

Our questions concerning the changing role of state and experts in this chapter are much the same as Ozga's (2015: p. 30) note on the paradox of "fundamental commitment to reducing the role of the state and enabling system and self-regulation through the market" and "the need to use state regulation in order to get the market to function properly", which in turn "is creating constant pressure for increased regulation and centralization". Citing Kandel (1938: p. 29), she warns: "The danger that confronts mankind to-day comes not 
from the expansion of education, but the specialization in some narrow corner of the field of knowledge. The specialist faces the world to-day as the blind man the elephant and fails to see life steadily and see it whole" (Ozga 2015: p. 31).

\section{The context of expertise}

The complexity of governance, and thus the operating environment for experts, is increasing. Bob Jessop (2002: p. 199) calls this “destatization", which involves "re - drawing the public - private divide, reallocating tasks, and rearticulating the relationships between organizations and tasks across this divide". Alongside these changes global education policy communities are constituted through which new policy discourses and narratives flow. The new global policy networks are built by a

diverse set of think tanks, consultants, multi - lateral agencies, donors, education businesses, and philanthropies, [which] constitute policy communities that are based upon shared conceptions of social problems and their solutions. New narratives about what counts as a 'good' policy are articulated and validated.

(Juneman, Ball, \& Santori 2016: pp. 537-538; Ball 2007)

Private providers are now also involved at different levels and scales, through advice, consultation, evaluation, philanthropy, partnerships, representation, programme delivery, and outsourcing in the provision, monitoring, and evaluation of public-sector services. This has "brought new players, voices, values, and discourses into policy conversations" and "governance by networks": "webs of stable and ongoing relationships which mobilize dispersed resources towards the solution of policy problems" (Pal 1997; cited in Juneman, Ball, \& Santori 2016: p. 537). The situation is of course somewhat different in Brazil, China, and Russia, but most of these private providers have gained a foothold in them as well (see Chapters 6 and 7).

Data and data systems support the growing activity of expert networks, which aim to identify and frame policy problems and solutions nationally. Networks of new actors and experts also exist. A major expansion of education consultancy and provision of educational goods and services contributing to the promotion of standardised testing and "standardizing doxa of best practices" is taking place. A range of sophisticated standardisation instruments, quality benchmarking, and data harmonisation "underpin[s] the governance turn[s] and act[s] on and within the national systems promoting ways of controlling and shaping national, institutional and individual behavior". New data enable the state to work on schools and localities as a resource for steering state policy in its entirety and compel experts to move "beyond the traditional task of informing policy and [become] policy forming in a more complex form of governing" (Fenwick, Mangez, \& Ozga 2014: p. 5). 
In defining the function of experts, Lawn and Segerholm (2011: p. 45) emphasise the transnational nature of their work:

Experts aid the flow of data across countries, and so act to constitute a new spatial infrastructure to emerge around education. Through shared databases, policy officers, technical experts and meetings, new synapses operate through which messages of comparison and commensurability (messages of standards, ranking scales, indicators and benchmarks) are passed.

All this is happening between national agencies and the OECD, which are the major players in constructing a common education space through the flow of data. Data may be called "the currency of governance". Similarly, Fenwick, Mangez, and Ozga (2014: p. 4) claim that to understand and capture globallocal interactions, we should take seriously Sassen's (2010: p. 10) injunction to think of the "global - whether an institution, a process, a discursive practice, an imaginary - as both transcending the exclusive framing of nation states and partly emerging and operating within that framing".

In developing countries, education policy has relied on the discursive construction of state failure (for example, in limited access and poor quality). Robertson and Verger (2012) suggest a strong generalisation regarding the "developed" world has been accompanied by "a purposeful framing of causes and issues (failing state, lazy teachers, lack of incentives, lack of accountability, dysfunctional schools) and a selective use of evidence". These have been articulated by "neo-liberal rationalities that link market mechanisms such as choice and fee payment to greater accountability and education quality" (Juneman, Ball, \& Santori 2016: p. 538). However, this is not especially characteristic of Brazil, China, and Russia, where choice and fee payment are concerned.

The governance of education is thus increasingly understood as taking place through cross-sectoral networks of public, private, and third-sector interdependencies which crisscross national and transnational boundaries. This "networked governance" is decentralised and characterised by fluidity, looseness, complexity, and instability (Ozga, Dahler-Larsen \& Segerholm 2011; Williamson 2012). Post-bureaucratic networked governance is conceived as "soft power", which works

through techniques of attraction, seduction, persuasion and the cultivation of support and shared interest across networks of loosely associated actors. Soft forms of governance include self-regulation, self-evaluation, selfgovernance and governing through the capacities of the governed, rather than the hard government of centralized targets and external regulation.

(Williamson 2014: p. 218)

Our analysis sees experts as actors practising "a specific activity of knowledge production participating in the process of negotiation and orientation of public educational policy" (Normand 2017: p. 74; see also Ozga 2011; 
Lawn \& Normand 2014). In the following empirical section, experts are those engaged as consultants, researchers, scholars, and lecturers in the field of education.

\section{The state and expertise in Brazil}

The Brazilian expert community is strong and has already been transnationally linked for many decades (Kauko et al. 2016). In Chapter 4, we observed that the changes in agenda partly relayed by these networks have transformed the political constellation of actors in Brazilian polity. In this chapter, we focus more on the potentially most influential expert body.

The experts in Brazil recognised as responsible and legitimate actors for the collection and interpreting of QAE data in the field of school education policy are located in the main national expert body for large-scale assessments, the National Institute for Educational Studies and Research (INEP), which is responsible for Brazil's main education indicators, such as the Index for Development in Basic Education (IDEB). There are other important expert bodies, third-sector movements, and think tanks in the Brazilian expert community, but none surpasses the INEP in its scale of data production, which is why we concentrate on this organisation in analysing the changing role of expertise. To tease out the answers to this chapter's central questions, we need to investigate interviewees' descriptions of the scope and potential of the INEP on different levels of action.

Our chapter focuses on the nature of the relationship and division of labour in Brazil between the state and experts. We have already adduced evidence of this change in Chapter 4. In this chapter, we observe a strong willingness to cooperate with the INEP on different levels. Policymaker interviewees described the INEP as a close collaborator. The Chamber of Deputies Standing Committee on Education, for example, holds expert hearings with the INEP and Ministry of Education (BR-N-11, written communication). The INEP also closely collaborates with the Ministry of Education in producing analytical tools (BR-N-02). However, at the sub-national state level, there is more demand for training than the INEP can offer (BR-N-09). In this sense, in relation to the scope of the INEP's operations, we can see that it receives strong legitimisation from different actors.

Our interviewees also pointed to the principle that the Ministry of Education is not allowed to deal with political questions at sub-national levels. One interviewee stated that large-scale assessments still provided the Ministry of Education with information regarding work in the great majority of municipalities and states but allowed such separation and non-involvement. Indeed, the interviewees' wording indicates there is no willingness in the Ministry of Education to use large-scale assessment as a tool:

The Ministry of Education does not aspire to have more political power in the field of educational policies in the area of basic education ... [T]he 
formulation of large-scale assessments is certainly not a strategy to gather more power.

In analysing whether Brazilian experts, state authorities, and policymakers are willing to limit and restrict or widen and open data use in practising education policies grounded in QAE, our interviews suggest that the INEP has more power than it currently exerts. However, there were contradictory understandings of how independent the INEP was of the political process. An INEP expert argued for more autonomy for the organisation. This interviewee described an incident in which it was alleged that the INEP was postponing publication of a report because of government pressure. Our research cannot verify if this happened, but it indicates actors' perception that the Ministry of Education retains some influence on the publication of results and that the INEP is not completely independent.

Then it happens, eventually . . The ministry interferes, saying "Wait a moment, calm down, for me this isn't a good time for you to say that, there is an election now, in a little while, then no, no, it is not so interesting to publish that." No one will interfere in an autonomous institution, but it needs to be $100 \%$ autonomous. With the dissemination of some results, last year it was questioned, regarding the deadline, if there was interference or not. I would not be able to tell you, but I'll tell you that if there's a cat's tail, a cat's ear and it meows it is probably a cat. I do not know if there was, but there's some reason to think so. I would expect the INEP to be more autonomous than that.

(BR-E-06)

In analysing experts' and policymakers' willingness to limit and restrict or widen and open data use in practising the education policies grounded in QAE, we found that, although there is no consistent view, the self-understanding of the INEP was more that of an expert than a policymaker, which created difficulties with political issues, as the preceding quotation indicates. However, some also emphasised that the INEP was almost a prerequisite for decision-making and that without it there could be no policy monitoring.

The INEP's status is as a national agency, meaning it has relative autonomy with respect to the Ministry, but maybe it is one of the agencies that suffers a more direct impact from policy decisions. [The INEP is] subject to political decisions with little dialogue. It is also my perception that there is little dialogue and it feels ... that we are often performers and that goes against the identity of the researcher. This is the dilemma that we suffer: how can I be a researcher if I feel I am a political performer? It's like I don't have ... I can think but I can't perform what 
I think but what someone has told me to do. It's a pretty important ambiguity.

(BR-N-09)

The main data of Brazilian education today are produced here within the INEP. Information is fundamental not only for the elaboration of policies but for monitoring of policies. Do you understand, then for example, there is work done by the Presidency of the Republic on problems, inequality in Brazilian schooling, etc.? They constitute an observatory for the Presidency of the Republic and the data are collected by the INEP, you understand, so without the information provided by the INEP you cannot only elaborate the policies but monitor them.

(BR-N-04)

A different view was offered by a state-level politician, who pointed out that a major reform of the matriculation examination (vestibular) was being implemented without consulting experts.

In 2009 the Minister decided that he would replace, roughly speaking, the Brazilian vestibular but had no dialogue with the team, no internal dialogue to find out what this team of researchers thinks about it.

(BR-N-09)

It might be concluded that the large-scale assessment data the INEP collects allows it potential room for action, but this potential is not realised because of the actor relations and set practices just described. However, the organisation can address problems through public discussion. Although it was alleged politicians were trying to influence the INEP, we observed no consistent pattern, and in general, the organisation seemed quite autonomous. Chapter 6 points out that interviewees reported policy processes in which although the INEP's expertise is available, policymakers do not always consult it in preparing important decisions. Its role is ambiguous: the Ministry of Education's distance and the INEP's orientation do not support political interference, but in some cases, the political process finds its way around the experts.

\section{The state and expertise in China}

In China, expertise and the state have an entwined relationship that is ingrained in the Chinese culture of meritocracy, which "originated in the philosophies of Confucianism and Daoism during the fifth and sixth centuries BC and developed with the Legalists in the subsequent centuries" (Liu 2016; Yao 2000). The Confucian stance on this issue is that an excellent student or scholar should pursue a political career and an excellent politician should also become a good scholar (see Legge's translation 1983). Pursuing a political career was the only 
proper goal of education in the context of Confucianism. Liu (2016) writes that the direct manifestation on the institutional level was the civil service examination system known as kejju through which the government selected government officials. Those who passed kēju became government officials and were given power and authority to govern because of the trust the educated enjoyed as a result of their knowledge and expertise, which enabled them to better understand how to govern or manage social issues. However, those who did not fit into the system often chose to serve the aristocracy as advisers móu shì. The civil service examination system was abolished in 1904, a few years before the end of the last Chinese imperial era. But the legacy of meritocracy remains deeply rooted in Chinese culture, and this is manifested in the current political system in elite governance or authoritarianism (Han \& Ye 2017).

The relationship between expertise and the state best explains the contemporary meritocracy. Our findings reveal that policymaking expertise is largely provided by researchers from various domestic and foreign research institutions and universities. They still play the role of advisers to policymakers, assisting them to understand what the real problems and possible solutions are. The final decision in policymaking remains in policymakers' hands, however (Han \& Ye 2017).

When we seek to identify the main experts in China recognised as responsible and legitimate actors in collecting and interpreting data in the field of QAE policies, we observe that the state usually collaborates most directly and closely with top-ranked universities and research institutes associated with the central government. Traditional units, such as research institutes, universities, and even researchers, may to some extent collaborate with the state through applying for funding from state-funded foundations or being directly appointed by the state to collect data. Social connections play a major role in the allocation of such cooperation opportunities (Buckley, Clegg, \& Tan, H. 2006; Park \& Luo 2001; Wong \& Tam 2000), which enables researchers with more extensive social and political connections to receive more academic research projects from the government. Another approach of the state is to establish new research centres or institutes based on government planning of the political agenda. An example is the National Assessment of Education Quality (NAEQ), which was established in 2007 to collect nationwide standardised testing data (Zhou et al. submitted). New testing contrasts with the traditional examination method, which has been the dominant means of evaluating, assessing, and ranking students' learning outcomes. However, this new testing carries the ambitious political task of diagnosing the "real" education problems with reliable and sophisticated empirical data. It is creating a nationwide databank based on the annual assessment of students' academic performance and other elements influencing such achievement. To accumulate indicators for this new testing system, the state has established a special NAEQ centre, employing researchers from top universities both in China and from abroad (Zhou et al. submitted). The official newsletter of the NAEQ states that more than sixty universities and research 
institutions are involved in the testing of indicators for different school subjects. This testing has been inspired by many large-scale assessments like the Programme for International Student Assessment (PISA) and NEPS (the German National Educational Panel Study).

When we ask what kind of relationship and division of labour exists in China between the state and experts and if there is evidence that the relationship is changing, we observe that the state tends to rely increasingly on evidencebased data. Besides the new testing system, the state is also the main resource for research funding. Many research foundations, such as the National Planning Office for Philosophy and Social Sciences (NPOPSS), are among the largest state foundations. An indication of this increasing tendency is that the NPOPSS has started to fund more education projects. In 2015, the NPOPSS funded a total of 202 projects (NPOPSS 2016) covering broadly educational topics. In 2011, when data collection concerning this began, it funded 167 (NPOPSS 2011).

The Chinese state channels academic research focus. Government funding is usually used by the state as a pre-policymaking test. Research proposals therefore share the concerns of the government's agenda. The state signals the government's agenda or focuses through documents and leaders' speeches. Newspapers and academics then focus on these topics. For example, one of the main concerns of the government is how to solve the imbalanced distribution of education and social resources, and QAE's academic research seeks to take this concern into account in using QAE to achieve this. This issue was repeatedly mentioned by various interviewees. It is commonly understood that if someone wants to receive government funding for their research project, their proposal needs somehow to be connected with the topics prioritised by the government agenda. One interviewee stated,

Our country [refers to the government], for example, now emphasises the importance of college entrance examination reform, so we will focus on this ... in the college entrance examination reform [of group publications related to this issue]. For example, we will ask how to change the college entrance examination, how to use the academic achievement test in the college entrance examination, how to operate the academic achievement test ... and then our focus will be transferred to these issues.

(CN-E-08)

Experts play the role of knowledge-broker to inform the state and other stakeholders about the situation of education, based on their research results. They have connections both with the state in decision-making and with schools in implementation. Both connections mean that experts influence decisionmaking through the utilisation of their research results' evidence and authority.

[T] hrough this analysis [refers to their project] ... [our] main purpose is first to go to help the schools. By analysing the results of the teaching process, we hope to help them [refers to teachers and schools] 
to improve teaching and situations, and their research results are also reported to the government for policymaking reference. The second purpose is to report the situation to the government so that they can learn about situations in schools to reflect on policymaking. Our second task is to do policy research to help the government with improvement of policy.

(CN-E-11)

Experts are largely involved in the consultation stage, but whether the decisionmaker accepts the results and the extent to which schools can change their practice appear to be problematic areas. The state has the final decision concerning policymaking. A rector of a prestigious research institute told us how much their work can influence policymaking:

The government listens to different voices ... When a researcher delivers a report based on their findings, the government starts to hold different meetings to listen to voices from different levels. For instance, how parents think about or feel about this policy. After many rounds of meetings the government publishes the final version of the policy, which looks a bit like a decision based on your findings and also a bit like a decision based on other researchers' findings.

(CN-E 06)

Policymakers and experts appear to have become a mutual benefit community (Han \& Ye 2017), which helps and promotes their respective agendas. National policymakers have the widest choice of national, local, and international academic resources, but they are most likely to cooperate with researchers from an equivalent level. For example, the central state usually selects institutes based on their reputations and ranking. Likewise, provincial decision-makers generally receive academic support from regional universities. Data are more likely to be circulated within a political group and among key stakeholders. However, policymakers and experts do not really form a community. The boundary is clear. The researcher is responsible for data production, while the government is responsible for the production of policy based on these data: "It is government's responsibility to decide when and how to release it" (CN-E-07).

In investigating the willingness of Chinese experts and state authorities and policymakers to limit and restrict or to widen and open data use in their practice of QAE education policies, we observe that national and provincial governments prefer to utilise research results from various sources to support their decisions, and even policymakers themselves become experts on data and numbers. These various sources generally emanate from an individual researcher, a research group or team, research institutes, and specially funded problem-based research centres. The Chinese government has supported prestigious Chinese universities in growing their research competence in the global education 
market through their involvement in international academia in increasing impact factors, rankings, and publications.

The Ministry of Education has multi-channel resources. We have the National Bureau of Statistics which is the authority for all types of statistics. Most documents and policies draw data from this place. The Ministry of Education also uses universities, research institutions, and local governments to provide data to the Ministry of Education.

(CN-E-07)

However, these multi-channel resources only fit the national level. Distribution of expertise is uneven. Skilful experts are recruited from national universities and serve in national policymaking. At the local level, however, there are fewer expert resources.

There are two skins [two separate sets of actions which have little connection] in terms of reforms of educational assessment and evaluation. The indexes created at national level introduced a new concept of evaluation, and designed an assessment process ... so the provincial government, including the county government, coordinates the assessment. Then the results go back to Beijing [the central government] and have no relationship with locals. So, the locals just continue the old practices, following the traditional ways like supervision because they know them well.

(CN-E-12)

However, implementation of central policy depends on the regions. Local government and schools in most Chinese regions are not equipped with equally skilled and knowledgeable experts, which may harm implementation and make a real difference at the local level.

\section{The state and expertise in Russia}

Russian experts contribute to international, national, and sub-national discussions on education and maintain communication between these levels. From the state's perspective, they are legitimate actors responsible for collecting and interpreting data in the field of QAE compulsory education policy. Some worked in federal agencies during the 1990s and later moved to the research sector, which focuses on measurements and the analysis of their results. Although they are autonomous in their international communication, instrument planning, and collaboration with the regions, their projects are often stimulated by the state's targeted financing, or they need to look for sub-national partners and funding to sustain their research work.

International contacts ensure awareness of education developments elsewhere. Technical and other innovative ideas are applied in national tests and in developing and analysing test items. For example, this occurred when PISA-like 
assignments were introduced to the Unified State Exam (USE) after national specialists participated in seminars in the Netherlands (RU-E-12). Communication with colleagues from abroad stimulates the growth of national expertise concerning assessments. The interviewed experts insist that this was not a unidirectional relationship in the 1990s, since Russian experts were not passive recipients of assistance and guidance from international agencies. From an early stage they have collaborated internationally on equal terms.

It is well-known, publicly available, that [international] colleagues did a lot for the development and acknowledgement of the Russian instruments. It would be wrong not to mention this. However, this is a big collaborative work. It is impossible that someone came from abroad, an expert, however qualified he is, but it is impossible to come to the territory, country, and change something there. It would be wrong. If the team has been formed, if there is a constructive moment ... dialogue, then everything changes, you can take the best, and there is a partner-like relationship, it is important.

(RU-N-02)

Attaining knowledge on the specifics of the system of education spurred the advance of the assessment instruments; later changes included defining education standards and development of textbooks. However, the connections on this level show the primacy of the state in defining the agenda, while experts foster the discussion about the problems of the education system.

(RU-E-04)

The relationship with sub-national and school-level specialists is more collaborative. The development of new instruments, for example, an assessment of children's readiness for school and subsequent assessments across primary schools, occurs through cooperation. This means reorienting schools towards development based on available data and giving teachers the opportunity for discussion and reflection. In this case, experts involve school specialists in education analysis, and they maintain the link between nationally identified priorities and practices (RU-E-12).

However, the federal government is the major player in data production, analysis, and dissemination:

You know, everywhere, always we continued because for the primary school we had a project of Rosobrnadzor. It means that there is an organisational structure, money, people, plan, results which you aim to achieve. Plus, you add something of your own, what you think is important to develop in this direction.

For example, when Rosobrnadzor's support switches to other initiatives, experts and school-level specialists have less room for action. They are unable to 
continue with initiatives they have already started, because the state focuses on the new instruments.

Another example of experts' collaboration at the sub-national level is their analysis of the situation of schools facing challenging circumstances. This is a matter of current national interest and therefore receives support. Since there is less federal regulation, at least currently, there is more room for action for experts and school-level specialists (RU-E-04).

Even when the analysis demonstrates a need for change, there are problems in developing practical solutions. Specialists are needed who will collaborate with schools and regional governments (RU-E-07). Teachers should be able to understand tests and the objective assessment system (RU-E-10).

Finally, media actors collect data about rankings from open sources. An example of such a project is "Social Navigator", an agency and web resource which aggregates information about public services for extensive social use. They present their work as being about public accountability rather than the pursuit of scientific goals, which is a key difference from the experts' focus. They promote key findings for the information of the public and do not strive to influence governance (RU-E-11).

The relationship and division of labour between the state and experts in Russia is built around data collection, ownership, and analysis. Its utilisation by different actors varies, depending on their analytical interests and their decision-making power in education. The evidence of change is manifested in the state's greater presence at all these stages. The ministry limits experts' access to large-scale data, and decisions are often not based on open professional discussion. The state stimulates the development of new instruments, but when there is a shift towards new funding priorities, the regions struggle to sustain these initiatives.

Experts connect transnational and national education policies; international assessments help experts in legitimising certain ideas on the state level, although there is often a delay in implementation:

I think we always work in advance, this is the feeling of the time-frame of our activity, because the expert world is much more saturated with information. We travel somewhere, we read, and we get rushed. We want models, approaches, and ways of life to work everywhere, to work where we are. Then, this time lag emerges, and we feel that nothing happens. And if after some time some documents articulating education policies emerge, there is a signal from above [informal approval of the state officials], it is hard to understand if we weren't involved. What we did before was to create an information field and discussion, because we don't write just for ourselves, you know. It all emerges in the press and becomes a part of the public discussion.

(RU-E-04)

Typical situations creating political opportunity are presented when performance in some test is particularly low, and the analysis identifies problems 
(see Piattoeva \& Gurova 2018). An example is PISA and the discrepancy between its results and those of the Progress in International Reading Literacy Study (PIRLS), which has pointed to the weakness of students' curriculum knowledge-transfer to applied tasks (RU-E-12). These cases validate experts' ideas in the eyes of state officials.

Experts' influence on the agenda is limited because of the state's ownership of data. Moreover, the interest and approval of state officials determine the development and application of any instrument and subsequent data gathering and analysis.

However, the state is also empowered by data, which creates a need for relevant statistics to support current policy priorities. This stimulates a selective approach to statistics, in which only suitable information is extracted to justify an agenda, instead of decisions being developed through data analysis. Specialists criticise this case-driven use of inferences which diminishes the demand for analytical work.

However, even when specialists have an opportunity to offer analytical support, their expert advice is often unappreciated:

Look, there is an expert who is asked, he has to respond. I would say it is a problem when they [government officials] ask. If they first ask, and then you answer, so that someone can take it into consideration, I think this is okay. But if something is done, decided, and then they ask you for some reason. For instance, there was recently a discussion in the Civic Chamber, the ministry presented a model of the graduate portfolio, the portfolio of a university graduate. We came there, they did not invite us, we just came. We tried to comment, and the answer was "everything is already decided".

(RU-E-04)

Moreover, when cabinet positions change, the pool of trusted experts is reformed. Several experts we interviewed used to work in the governance structures of the 1990s, but they are now occupied with analytical work. Other specialists are more aligned with governance structures.

The question of whether Russian experts and state authorities are willing to limit, restrict, or widen data use in practising QAE education policies reveals acknowledged problems both in data collection and its application in decisionmaking. Although there is an abundance of statistics on many issues, a key datarelated problem for experts is their uneven collection. For example, context data about schools were previously available in the "school social passport", but this instrument was cancelled. Given Rosobrnadzor's desire to promote evidence-based decisions, experts' hope is that once a specific data deficiency is identified, officials will request a specialist consultation. However, the education managers and state officials who order such instruments often fail to understand the kind of instruments which might be developed. The cost of undertaking tests also precludes development in this direction. When large data sets are accumulated, sufficient specialists for every school district are required to 
analyse them (RU-E-02). Monitoring is discussed as the next goal of the education system's transformation, which will assemble an all-encompassing set of indicators, but there is a concern about how this data will be used (RU-E-04). Although efforts are made to base decisions on them, experts are sceptical about how management is exercised in education policy:

It is called evidence-based decision-making, but it is exotic for our country. We don't have that for sure. The decisions are still being made based on opinions: the one who is louder, who has a higher status, who is more respected, is the one whose opinion is heard more. In that sense it is good that this is already articulated.

(RU-E-02)

It is understood that "it is important to note who showed you that piece of data". Its use is often determined by a need to demonstrate something on the spot (RU-E-03). Specialists are concerned about how state officials handle data, because their insights are frequently ignored (RU-E-03).

The attitude to rankings explains the difference in the positions of experts and education managers. The proponents of this instrument claim it should be used for general information purposes as a quick illustration, supported by extensive data (RU-N-04; RU-E-05; RU-SN-1). However, experts point to the scarcity of publicly available data from which rankings are drawn (RU-E-11). Officials acknowledge that rankings do not allow an analysis of the circumstances of poor-performing schools, which is among the governance priorities (RU-N-04). The instrument does not address challenges in attaining good results. Yet results are often used to praise or admonish educational institutions, because education managers lack the skills to interpret data.

There is a general mismatch between the demands of experts, who refine the measurements in their scientific work, and state officials, who seek justification for the policy agenda. Specialists exercise autonomy within their analytical work, but this depends on government funding and access to data.

\section{Conclusion: the changing role of the state and room for experts in QAE policy in Brazil, China, and Russia}

This chapter's aim was to analyse and contextualise the changing role of and relationship between the state and expertise in Brazil, China, and Russia when large-scale quality assurance policies and evaluation in school education are undertaken. We examined more closely how the nature of expertise reshapes the state's context, status, potential, and limits in implementing and governing education reform.

As already indicated, the previous research on governance and expertise emphasises the state's changing role, the complexity of national decisionmaking, and a shift to a regime of governance by numbers. This is partly true in how both expert communities and the state are willing, at least rhetorically, 
to build a community in which shared interests benefit from cooperation. For example, in Brazil, we find a strong willingness to cooperate with the INEP on different levels. In relation to the INEP's operational scope, we observe that it receives strong legitimisation from different actors. In China, the state also tends to rely increasingly on evidence-based data, even to the extent of establishing a new testing system. In Russia, independent experts exercise extensive autonomy in indirectly influencing education content. The state and experts cooperate, with experts providing analytical assistance, while the state owns data. The state now demands increased data collection.

Our analysis confirms that some of the claims presented in previous research from a global perspective may slightly exaggerate the situation in Brazil, China, and Russia. Expert bodies certainly have some power and, more specifically, potential for power. However, the state and expert communities influence the whole of society and community. There are tensions between controlling data and being controlled by it and who interprets and who publishes data. These tensions are more visible in some cases than others. In Brazil, for example, the INEP is perceived as quite autonomous, and it enjoys public trust, yet it is not entirely free of political influences, which to some extent call into question its autonomy. If an expert body's orientation does not support a political proposal, the political process can find a way of circumventing the experts. A similar phenomenon can be seen in China. Both national and provincial governments have always looked for data and academic research results from various sources to support their decisions, but they have always been the final decision-makers concerning which and whose data to use. In Russia, although there is an abundance of figures on many issues, experts' key data-related problem is its uneven collection. For example, context data about schools were once available within the "school social passport", but this was cancelled. Independent experts have limited access to state-owned data. The ministry accumulates data to support evidence-based policy without extensive professional discussion. The results of the USE are unavailable for academic analysis unless they are acquired from individual schools (which is problematic for large-scale analysis). At the same time, USE results and other data are widely used in rankings. There is therefore a scarcity of context data, such as regional socio-economic indicators. These deficiencies impede "rule by data". In Russia, the state can limit and restrict data use.

Policymakers' and experts' basic relationship with assessment data use differs. Whereas policymakers can work with or without data, experts depend on it. Whereas policymakers can bend interpretations, experts attempt to adhere to what is analysed. Experts' independence from state organs is another important issue. These differences in understanding data use also reflect the basic dynamic of the relationship between the state and experts.

There is a clear convergence in QAE politics in Brazil, China, and Russia: all have striven to expand the collection and use of QAE data by experts. States have established new institutions and organisations to widen QAE practice. The scale and growth of expert participation in QAE formation and interpretation 
have been impressive, and many of the characteristics of the "expert state" have emerged. However, there is a clear boundary for such expert participation. In each country, the division of labour in QAE and the possible limitations and restrictions of data use have been discussed. Experts are trusted to produce and collect data, but full usage of data is to some extent restricted or interfered with by political agendas.

However, Brazil, China, and Russia differ markedly in their history of collecting and using QAE data. Brazil has the longest history of institutionalising modern QAE data production and dissemination. In China, there has been a longstanding and very different tradition of pupil assessment, and the modern QAE system is relatively recent. In Russia, the tradition resembles China's more than Brazil's. We conclude that the state's role in QAE governance is more powerful in China and Russia than it is in Brazil.

\section{Bibliography}

Ball, S. J. (2007). Big policies/small world: An introduction to international perspectives in education policy. In B. Lingard \& J. Ozga (Eds.), The RoutledgeFalmer Reader in Education Policy and Politics (pp. 36-47). London \& New York, NY: Routledge.

Ball, S. J., \& Junemann, C. (2012). Networks, New Governance and Education. Bristol: The Policy Press.

Bauman, Z. (1987). Legislators and Interpreters: On Modernity, Post-Modernity and Intellectuals. Cambridge: Polity Press.

Bauman, Z. (1992). Intimations of Postmodernity. London \& New York, NY: Routledge.

Bauman, Z. (1998). Globalization: The Human Consequences. Cambridge: Polity Press.

Bauman, Z. (2004). Wasted Lives: Modernity and Its Outcasts. Cambridge: Polity Press.

Beck, U. (1999). World Risk Society. Cambridge: Polity Press.

Benz, A. (2004). Einleitung: Governance - Modebegriff oder nützliches Sozialwissenschaftliches Konzept? In A. Benz (Ed.), Governance - Regieren in komplexen Regelsystemen. Eine Einführung (pp. 11-28). Wiesbaden: VS Springer Verlag.

Benz, A., Lütz, S., Schimank, U., \& Simonis, G. (2007). Handbuch Governance. Theoretische Grundlagen und Empirische Anwendungsfelder. Wiesbaden: VS Verlag.

Buckley, P. J., Clegg, J., \& Tan, H. (2006). Cultural awareness in knowledge transfer to China - the role of Guanxi and Mianzi. Journal of World Business, 41(3), 275-288.

Dale, R. (2003). Globalisation, Europeanisation and the "competitiveness" Agenda: Implications for Education Policy in Europe. Paper presented to GENIE conference, Nicosia, Cyprus.

Dale, R. (2009). Contexts, constraints and resources in the development of European education space and European education policy. In R. Dale \& S. Robertson (Eds.), Globalisation and Europeanisation in Education (pp. 23-43). Oxford: Symposium Books.

Dale, R., Kazepov, Y., Rinne, R., \& Robertson, S. (2016). Scales, discourses and institutions in the governance of educational trajectories in Europe. In A. Walther, M. Parreira do Amaral, M. Cuconato, \& R. Dale (Eds.), Governance of Educational Trajectories in Europe: Pathways, Policy and Practice (pp. 55-74). London \& New York, NY: Bloomsbury Publishing.

Dale, R., \& Robertson, S. (2012). Towards a critical grammar of education policy movements. In G. Steiner-Khamsi \& F. Waldow (Eds.), World Yearbook of Education: Policy Borrowing and Lending in Education (pp. 21-40). London \& New York, NY: Routledge. 
Fenwick, T., Mangez, E., \& Ozga, J. (2014). Governing knowledge: Comparison, knowledgebased technologies and expertise in the regulation of education. In T. Fenwick, E. Mangez, \& J. Ozga (Eds.), Governing Knowledge. World Yearbook of Education 2014 (pp. 3-10). London \& New York, NY: Routledge.

Green, A. (1999). Education and globalization in Europe and East Asia: Convergent and divergent trends. Journal of Education Policy, 14(1), 55-71.

Han, S., \& Ye, F. (2017). China's education policy-making: A policy network perspective. Journal of Education Policy, 32(4), 389-413.

Jessop, B. (2002). The Future of the Capitalist State. Cambridge: Polity Press.

Junemann, C., Ball, S. J., \& Santori, D. (2016). Joined-up policy: Network connectivity and global education governance. In K. Mundy, A. Green, B. Lingard, \& A. Verger (Eds.), The Handbook of Global Education Policy (pp. 535-553). Chichester: John Wiley \& Sons.

Kandel, I. J. (1938). Problems of the University in Modern Society. The Educational Forum, $3,29$.

Kauko, J., Centeno, V. G., Candido, H., Shiroma, E., \& Klutas, A. (2016). The emergence of quality assessment in Brazilian basic education. European Educational Research Journal, 15(5), 558-579.

Kwiek, M. (2006). The University and the State: A Study Into Global Transformations. Frankfurt am Main: Peter Lang.

Lawn, M., \& Normand, R. (2014). Shaping of European Education: Interdisciplinary Approaches. London \& New York, NY: Routledge.

Lawn, M., \& Segerholm, C. (2011). Europe through experts and technologies. In J. Ozga, P. Dahler-Larsen, C. Segerholm, \& H. Simola (Eds.), Fabricating Quality in Education. Data and Governance in Europe (pp. 32-46). London \& New York, NY: Routledge.

Le Galès, P. (2004). Gouvernance. In L. Bousssaguet, S. Jacquot, \& P. Ravinet (Eds.), Dictionnaire des politiques publiques (pp. 242-250). Paris: Presses de Sciences Po.

Legge, J. (1983). The great learning, the doctrine of the mean, Confucius analects, the words of Mencius. Beijing: Foreign Languages.

Liu, Y. (2016). Origins of meritocracy in China. In Higher Education, Meritocracy and Inequality in China (pp. 11-34). Singapore: Springer.

Loncle, P., Parreira do Amaral, M., \& Dale, R. (2015). Introduction. In M. Parreira do Amaral, R. Dale, \& P. Loncle (Eds.), Shaping the Futures of Young Europeans: Education Governance in Eight European Countries (pp. 7-22). Oxford: Symposium Books.

Mayntz, R. (2004). Governance im modernen Staat [Governance in the modern state]. In A. Benz (Ed.), Governance - Regieren in komplexen Regelsystemen. Eine Einführung (pp. 65-76). Wiesbaden: VS-Verlag.

Mayntz, R. (2006). From government to governance: Political steering in modern societies. In D. Scheer \& F. Rubik (Eds.), Governance of Integrated Product Policy (pp. 18-24). Sheffield: Greenleaf Publishing.

National Planning Office of Philosophy and Social Science. (2011). Announcement of Education Projects Funded by NPOPSS. Retrieved from www.npopss-cn.gov.cn/GB/219468/ 15299041.html

National Planning Office of Philosophy and Social Science. (2016). Announcement of Education Projects Funded by NPOPSS. Retrieved from www.npopss-cn.gov.cn/n1/2015/1216/ c219469-27934440.html

Normand, R. (2017). Policy learning and expertise in European education. In R. Normand \& J-L. Derouet (Eds.), A European politics of education. Perspectives From Sociology, Policy Studies and Politics (pp. 73-91). London \& New York, NY: Routledge. 
Ozga, J. (2011). Researching the powerful: Seeking knowledge about policy. European Educational Research Journal, 10(2), 218-224.

Ozga, J. (2015). Working knowledge: Data, expertise and inspection in the governing of education. In H-G. Kotthoff \& E. Klerides (Eds.), Governing Educational Spaces - Knowledge, Teaching, and Learning in Transition (pp. 15-34). Rotterdam: Sense Publishers.

Ozga, J., Dahler-Larsen, P., \& Segerholm, C. (2011). Europe in translation. In J. Ozga, P. Dahler-Larsen, C. Segerholm, \& H. Simola (Eds.), Fabricating Quality in Education. Data and Governance in Europe (pp. 76-82). London \& New York, NY: Routledge.

Pal, L. A. (1997). Virtual Policy Networks: The Internet as a Model of Contemporary Governance? Proceedings of ISOC. Retrieved November 25, 2015, from www.isoc.org/inet97/pro ceedings/G7/G7_1.HTM

Park, S. H., \& Luo, Y. (2001). Guanxi and organizational dynamics: Organizational networking in Chinese firms. Strategic Management Journal, 22(5), 455-477.

Parreira do Amaral, M., \& Rinne, R. (2015). Reading discourses in the governance of educational trajectories of youth in Europe. In M. Parreira do Amaral, R. Dale, \& P. Loncle (Eds.), Shaping the Futures of Young Europeans - Education Governance in Eight European Countries (pp. 67-86). Oxford: Symposium Books.

Piattoeva, N., \& Gurova, G. (2018). Domesticating international assessments in Russia: Historical grievances, national values, scientific rationality and education modernization. In C. Alarcón \& M. Lawn (Eds.), Assessment Cultures: Historical Perspectives (pp. 87-110). Frankfurt am Main: Peter Lang.

Pons, X., \& van Zanten, A. (2007). Knowledge Circulation, Regulation and Governance. Literature Review (Part 6). Louvain: EU Research Project, Knowledge and Policy in Education and Health Sectors (KNOW\&POL).

Power, M. (1999). The Audit Society: Rituals of Verification. Oxford: Oxford University Press.

Power, M. (2003). Evaluating the audit explosion. Law \& Policy, 25(3), 185-203.

Rinne, R. (2001). Koulutuspolitiikan käänne ja nuorten syrjäytyminen [Cuff of education policy and the social exclusion of adolescents]. In A. Jauhiainen, R. Rinne, \& J. Tähtinen (Eds.), Koulutuspolitiikka Suomessa ja ylikansalliset mallit [Education policy in Finland and global models] (Vol. 1, pp. 91-138). Jyväskylä: Finnish Educational Research Association: Research in Educational Sciences.

Rinne, R., \& Ozga, J. (2011). Europe and the global: The role of the OECD in education politics. In J. Ozga, P. Dahler-Larsen, C. Segerholm, \& H. Simola (Eds.), Fabricating Quality in Education. Data and Governance in Europe (pp. 66-75). London \& New York, NY: Routledge.

Rinne, R., \& Ozga, J. (2013). The OECD and the global re-regulation of teachers' work: Knowledge-based regulation tools and teachers in Finland and England. In T. Seddon \& J. S. Levin (Eds.), Educators, Professionalism and Politics: Global Transitions, National Spaces and Professional Projects. World Yearbook of Education 2013 (pp. 97-116). London \& New York, NY: Routledge.

Robertson, S., \& Verger, A. (2012). Governing education through public private partnerships. In S.L. Robertson, K. Mundy, A. Verger, \& F. Menashy (Eds.), Public Private Partnerships in Education: New Actors and Modes of Governance in a Globalizing World (pp. 21-42). Cheltenham: Edward Elgar.

Rose, N. (1999). Powers of Freedom: Reframing Political Thought. Cambridge: Cambridge University Press.

Rose, N., \& Miller, P. (1992). Political power beyond the state. British Journal of Sociology, 43, 173-205. 
Rosenau, J. (1999). Towards an ontology for global governance. In M. Hewson \& T. Sinclair (Eds.), Approaches to Global Governance Theory. Albany: State University of New York Press. Rosenau, J. (2005). Global governance as disaggregated complexity. In A. D. Ba \& M. J. Hoffman (Eds.), Contending Perspectives on Global Governance: Coherence, Contestation and World Order. London: Routledge.

Sassen, S. (2010). "The global inside the national: A research agenda for sociology." Sociopedia.isa, online at: www.isa-sociology.org. In T. Fenwick, E. Mangez, \& J. Ozga (Eds.), Governing Knowledge. Comparison, Knowledge-Based Technologies and Expertise in the Regulation of Education. World Yearbook of Education 2014 (pp. 3-10). London \& New York, NY: Routledge.

Schuppert, G. F. (2006). Governance im Spiegel der Wissenschaftsdisziplinen. In G. F. Schuppert (Ed.), Governance Forschung. Vergewisserung über Stand und Ent-wicklungslinien (pp. 371-469). Baden Baden: Nomos.

Simola, H., Ozga, J., Segerholm, C., Varjo, J., \& Andersen, V. N. (2011). Governing by numbers. In J. Ozga, P. Dahler-Larsen, C. Segerholm, \& H. Simola (Eds.), Fabricating Quality in Education: Data and Governance in Europe (pp. 96-106). London \& New York, NY: Routledge.

Verger, A., Lubienski, C., \& Steiner-Khamsi, G. (2016). The emergence and structuring of the global education industry: Towards an analytical framework. In A. Verger, C. Lubienski, \& G. Steiner-Khamsi (Eds.), The Global Education Industry. World Yearbook of Education 2016 (pp. 3-24). London \& New York, NY: Routledge.

Weible, C. M. (2008). Expert-based information and policy subsystems: A review and synthesis. Policy Studies Journal, 36(4), 615-635.

Weiss, C. (1979). The many meanings of research utilization. Public Administration Review, 39(5), 426-431.

Weiss, L. (1997). Globalisation and the myth of the powerless state. New Left Review, 225, 3-27.

Williamson, B. (2012). Centrifugal schooling: Third sector policy networks and the reassembling of education policy in England. Journal of Education Policy, 27(6), 775-794.

Williamson, B. (2014). New governing experts in education: Self-learning software, policy labs and transactional pedagogies. In T. Fenwick, E. Mangez, \& J. Ozga (Eds.), Governing Knowledge. Comparison, Knowledge-Based Technologies and Expertise in the Regulation of Education. World Yearbook of Education 2014 (pp. 218-231). London \& New York, NY: Routledge.

Wong, Y.H., \& Tam, J. L. (2000). Mapping relationships in China: Guanxi dynamic approach. Journal of Business \& Industrial Marketing, 15(1), 57-70.

Yao, X. (2000). An Introduction to Confucianism. Cambridge: Cambridge University Press.

Zhou, X., Suominen, O., Fan, Y., Kallo, J., \& Rinne, R. (submitted). Reforms of Education Inspection in China from 1978-2015. 